\title{
M. Georgieva
}

\section{"Electrochemical Behavior of Pt(IV) on Mercury Electrode in the Presence of}

\section{Dimethylglyoxime"}

Volume 20, Number: 3/4, Year: 2002, pp.179-189.

\begin{tabular}{|c|c|c|}
\hline Page & Line & Error \\
\hline 179 & 3 & bis-dimethylglyoxi-mate \\
\hline 179 & Keywords & dime-thylglyoxime \\
\hline 181 & 20 & $\begin{array}{c}\ldots \text { negative values } \\
1.055 \mathrm{~V}) \ldots\end{array} \quad(\mathrm{Ep}=-$ \\
\hline 183 & Figure 2 & $\begin{array}{c}\ldots \text { peak current }(\mathbf{A}) \text { and peak } \\
\text { potential(B) } \ldots\end{array}$ \\
\hline 185 & Figure 4 & $\begin{array}{c}\text { Effect of the DMG } \\
\text { concentration on peak height } \\
\text { in... }\end{array}$ \\
\hline 187 & Figure 6 & $\begin{array}{c}\text { Dependence of the peak current } \\
\text { (A), peak potential }(\mathbf{B}) \text {, and }(\mathbf{C}) \text {, } \\
\text { on the scan rate in } 0.1 \mathrm{M} \text { acetate } \\
\text { buffer of } \mathrm{pH} 4.6,1 \times 10^{-4} \mathrm{M} \\
\mathrm{DMG}+15 \mu \mathrm{g} \mathrm{Pt} / \mathrm{L} \text {; deposition } \\
\text { time: } 2 \text { min at }-0.4 \mathrm{~V} \text {; electrode } \\
\text { area: } 0.028 \mathrm{~cm}^{2} .\end{array}$ \\
\hline
\end{tabular}

\author{
Correction \\ bis-dimethylglyoximate \\ dimethylglyoxime \\ ...negative values \\ $(E \mathrm{p}=-1.055 \mathrm{~V}) \ldots$
}

...peak potential(A) and peak current(B)...

Peak current dependence on preconcentration time in $0.1 \mathrm{M}$ acetate buffer of $\mathrm{pH} 4.6,1 \times 10^{-4} \mathrm{M}$ $\mathrm{DMG} ; \diamond-10 \mu \mathrm{g} \mathrm{Pt} / \mathrm{L}, \boldsymbol{\square}-15 \mu \mathrm{g} \mathrm{Pt} / \mathrm{L}, \mathbf{X}-25$ $\mu \mathrm{g} \mathrm{Pt} / \mathrm{L}$; at $-0.4 \mathrm{~V}$; electrode area: $0.028 \mathrm{~cm}^{2}$.

Dependence of the peak current (A), peak potential $(\mathbf{B})$, and $(\mathbf{C})$, on the scan rate and $\ln$ (scan rate) in $0.1 \mathrm{M}$ acetate buffer of $\mathrm{pH} 4.6$, $1 \times 10^{-4} \mathrm{M} \mathrm{DMG}+15 \mu \mathrm{g}$ Pt/L; deposition time: 2 min at $-0.4 \mathrm{~V}$; electrode area: $0.028 \mathrm{~cm}^{2}$. The same figure (D) shows the dependence of the peak current and peak potential at different scan rate; the other conditions are the same.

Figure 2 B (page 183) should be read as

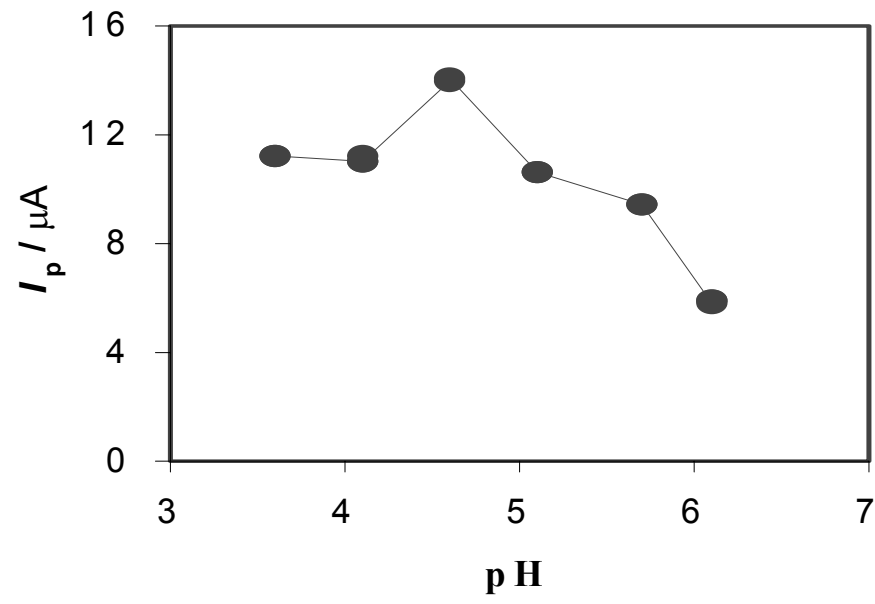

